\title{
Comparative Life Cycle Costing Analysis of Green Roofs: The Regional Aspect
}

\author{
Serdar Ulubeyli', Volkan Arslan ${ }^{1}$, Aynur Kazaz ${ }^{2}$ \\ ${ }^{1}$ Department of Civil Engineering, Bulent Ecevit University \\ ${ }^{2}$ Department of Civil Engineering, Akdeniz University
}

\begin{tabular}{l} 
Article Info \\
\hline Article history: \\
Received May $16^{\text {th }}, 2017$ \\
Revised June $14^{\text {th }}, 2017$ \\
Accepted June $17^{\text {th }}, 2017$ \\
\hline Keyword: \\
Benefits of green roofs \\
Extensive green roofs \\
Intensive gree roofs \\
Life cycle assessment \\
Life cycle costing
\end{tabular}

Corresponding Author:

Serdar Ulubeyli,

Department of Civil Engineering,

Bulent Ecevit University,

Incivez Mahallesi, Farabi Kampusu, 67100, Zonguldak, Turkey

Email: ulubeyli@beun.edu.tr

\begin{abstract}
The increasing environmental concerns and poor practices force construction industry to take some remedial measures for green and sustainable built environment. Especially in urban areas, one of these measures is to build green roofs for minimizing the environmental pollution. In fact, green roofs present a number of economic, environmental, and social benefits. However, compared with traditional roofs, green roof investments have high capital and maintenance costs and this makes potential investors hesitant about their applications. Therefore, in the present study, benefits and life cycle costing parameters of green roofs were evaluated through a literature review. In this context, numerical inputs and findings of past studies were utilized. In doing this, a special emphasis was placed on the regional characteristic of such investments as it is a natural feature of any life cycle costing analysis. In conclusion, the majority of benefits and life cycle costing parameters was found to be highly variable, and thus, any life cycle costing assessment that will be performed in the future should be case-sensitive instead of using some generalized or raw data. Therefore, based on findings and results of this study, industrial practitioners and potential customers may have a useful source of economic, environmental, and social information about green roofs while researchers may be encouraged for more region-specific studies.
\end{abstract}

\section{Introduction}

The sustainable built environment phenomena can be defined as providing both healthy environment for people through improving the quality of life and a livable future for current and next generations in terms of social, economic, and environmental conditions [1]. The construction industry, one of the leading industries in developed and developing countries, has an important role to improve social, economic, and environmental conditions of the sustainable built environment. However, it is responsible for high values of energy and resource consumption, solid waste production, and greenhouse gas emission [2, 3]. These adverse effects force the construction industry to take some preventive measures to reduce its environmental damage to a minimum level. Today, green roofs are chosen both as a technological device that has potential to decrease energy and pollution based environmental problems and as a construction application that can minimize the lack of green fields in urban areas in many countries around the world [4]. This is because they present numerous benefits for societies and individuals, such as savings from energy and storm water [5], fall in the temperature of roof membrane [6], improving air quality [7], rise in habitat and biodiversity [8], mitigation of 
urban heat island effect [9], noise reduction and aesthetic view [10], and formation of recreation areas [11]. However, due to high initial and maintenance costs, they have not attracted the required attention of clients so far in many countries. For example, in some regions in Germany and Japan, green roof applications are mandatory [12]. As another instance, the Korean government subsidizes 50\% of the initial investment cost of green roofs implemented in major cities [13]. Thus, in order to encourage investors for green roofs in practice, it seems to be necessary to present their economic advantages in the long term through the analysis of their lifecycle costs besides environmental benefits.

Therefore, the aim of this study was to provide a useful source of financial information about green roofs for industrial practitioners and to encourage researchers for more region-specific studies as life cycle costing naturally needs and demands a regional resolution [14]. For this purpose, past studies concerning life cycle costing of green roofs in the literature were comparatively analyzed. In this context, a number of indicators such as unit construction cost, lifespan, life cycle costing method, interest rate, and economic, environmental, and social benefits were presented given their regional aspects.

\section{Materials and Methods}

In the literature, there are a few dozens of studies that compare green roofs applied in different geographical regions. However, it was seen that, in these studies, only two or three different cities were compared with each other [15-17]. It means that the literature seems to lack a comparative life cycle costing study emphasizing the regional aspect of green roofs as a whole. Therefore, in the present study, this type of past researches was divided into two sub-categories as extensive (Table 1) and intensive (Table 2) green roofs by reviewing the related literature and was compared in terms of unit construction cost, life span, life cycle costing method, and interest rate in a regional manner. Moreover, in order to compare and reveal the potential regional variability of benefits, they were individually investigated from the economic, environmental, and social point of view.

Table 1. Life cycle costing studies on extensive green roofs

\begin{tabular}{lccccc}
\hline \multicolumn{1}{c}{ Authors } & Country & Unit Cost $\left(\$ / \mathrm{m}^{2}\right)$ & Method(s) & $\begin{array}{c}\text { Lifespan } \\
(\text { year })\end{array}$ & $\begin{array}{c}\text { Discount } \\
\text { rate }(\%)\end{array}$ \\
\hline Porsche and Köhler [15] & Germany-USA-Brazil & $85-90$ & NPV & 90 & n.a. \\
Zhang et al. [16] & Germany-Singapore & 31.72 & NPV & 40 & 5 \\
Clark et al. [4] & USA & 232 & NPV & 40 & 5 \\
Carter and Keeler [5] & USA & 158.82 & NPV & 40 & 4 \\
Blackhurst et al. [9] & USA & 97.04 & BCR & 30 & 5 \\
Niu et al. [18] & USA & 306 & NPV & 40 & $6-7$ \\
Wu and Smith [19] & USA & 107.64 & PBP-NPV-BEP & 40 & 2.8 \\
Bianchini and Hewage [20] & USA & $130-165$ & NPV-PBP & $40-55$ & $2-8$ \\
Mullen et al. [21] & USA & $158-306$ & NPV & 40 & n.a. \\
Sproul et al. [22] & USA & 172 & NPV & 50 & 3 \\
Joksimovic and Alam [23] & Canada & 236.45 & NPV & 50 & 5 \\
Peri et al. [24] & Italy & 75.05 & NPV & 40 & 6 \\
Angelakoglou et al. [25] & Greece & $90-180$ & PBP & 25 & n.a. \\
Claus and Rousseau [12] & Belgium & 141.9 & NPV & 50 & 4 \\
Tsang and Jim [26] & Hong Kong & 150 & NPV & 40 & 5 \\
Chan and Chow [27] & Hong Kong & 68 & NPV-PBP & 25 & 4.25 \\
Peng and Jim [28] & Hong Kong & 64 & BCR-PBP & 40 & 4.25 \\
Lee et al. [29] & South Korea & 134.5 & n.a. & $2-100$ & n.a. \\
Shin and Kim [30] & South Korea & 23.32 & BCR & 20 & 5.5 \\
Liu and Hong [31] & China & 241.2 & BCR & 40 & 5 \\
Wong et al. [32] & & & NPV-SIR- & & \\
& Singapore & 89.86 & AIRR-PBP- & 40 & 6.15 \\
\hline & & & DPBP & & \\
\hline
\end{tabular}


Table 1 includes extensive green roof researches that were analyzed in this study. Among them, Porsche and Köhler [15] compared green roofs in Germany, USA, and Brazil while Zhang et al. [16] examined green roofs in Germany and Singapore. The remaining ones can be categorized into three geographical locations as the American region (USA and Canada), the European region (Italy, Greece, and Belgium), and the Asian region (Hong Kong, South Korea, China, and Singapore).

Table 1 includes extensive green roof researches that were analyzed in this study. Among them, Porsche and Köhler [15] compared green roofs in Germany, USA, and Brazil while Zhang et al. [16] examined green roofs in Germany and Singapore. The remaining ones can be categorized into three geographical locations as the American region (USA and Canada), the European region (Italy, Greece, and Belgium), and the Asian region (Hong Kong, South Korea, China, and Singapore).

Compared with extensive green roofs, there are much less previous studies regarding intensive ones (Table 2). This may be because intensive green roofs have higher initial investment and maintenance costs and it would likely be a vain attempt to investigate their viabilities unless the feasibility of extensive green roofs is revealed. Although Porsche and Köhler [15] performed the single study about intensive green roofs in the European region, their research takes into account three different regions together. In other words, it neither focuses on nor presents a comparative perspective of the European region. Similarly, Chui et al. [17] compared intensive green roofs in Hong Kong and USA. Therefore, intensive green roof studies analyzed were categorized into two geographical locations as the American region (USA) and the Asian region (Hong Kong, Singapore, and Australia).

Table 2. Life cycle costing studies on intensive green roofs

\begin{tabular}{|c|c|c|c|c|c|}
\hline Authors & Country & $\begin{array}{c}\text { Unit Cost } \\
(\$ / \mathrm{m} 2)\end{array}$ & Method(s) used & $\begin{array}{c}\text { Lifetime } \\
\text { (year) }\end{array}$ & $\begin{array}{l}\text { Discount } \\
\text { rate }(\%)\end{array}$ \\
\hline Porsche and Köhler [15] & $\begin{array}{c}\text { Germany-USA- } \\
\text { Brazil }\end{array}$ & $340-380$ & NPV & 90 & n.a. \\
\hline Chui et al. [17] & Hong Kong-USA & $153-273$ & NPV & 30 & n.a. \\
\hline Bianchini and Hewage [20] & USA & $165-540$ & NPV-PBP & $40-55$ & $2-8$ \\
\hline Liu et al. [33] & USA & 168.34 & NPV & 20 & 4.5 \\
\hline Langston [34] & Australia & n.a. & BEP & $25-100$ & 3 \\
\hline Peng and Jim [28] & Hong Kong & 256 & BCR-PBP & 40 & 4.25 \\
\hline Wong et al. [32] & Singapore & $\begin{array}{l}178.93- \\
197.16\end{array}$ & $\begin{array}{c}\text { NPV-SIR- } \\
\text { AIRR-PBP- } \\
\text { DPBP }\end{array}$ & 40 & 5.15 \\
\hline
\end{tabular}

\section{Results and Discussion}

In this section, life cycle costs of green roofs was comparatively evaluated from a regional perspective to present the difference of the effect of costs and benefits. In the literature, the data used in life cycle costing studies can be grouped as primary and secondary data. Primary data represents the data provided directly from the manufacturer or market while secondary data is derived from the existing literature [35]. For the sake of reliability, primary data is preferred more to compile. In past studies about green roofs, unit construction costs and interest rates were usually used as primary data while lifespan and benefits were taken as secondary data. Here, monetary values of data were included using local values needed for the relevant region.

\subsection{Life cycle costing parameters}

Considering previous studies, it seems that there are three causes behind the green roof choice of clients. First, roof gardens in the USA are fashionable due to the positive effect of a better aesthetic view on the renting or selling price of a flat or an office since there is no legal regulation on rental rates as in Germany [15]. Similarly, in Brazil, people prefer roof flats with green terraces for a beautiful garden view and for an open green space required in tropical climates. Second, from the viewpoint of storm water management, energy and cost savings increase through the green infrastructure used in Germany instead of traditional rain water 
harvesting system in Singapore [16]. Third, cost-efficiency of green roof investments are more in the USA than Hong Kong because of higher land prices in Hong Kong [17].

Given unit construction costs of extensive roofs, they vary in a very large interval between \$97-306 for the American region, \$75-180 for the European region, and \$23-241 for the Asian region. Interestingly, the difference between the lowest and highest values in the same region can be more than ten times. Such an enormous difference is valid even in the same country such as USA, Hong Kong, and South Korea. However, taking the lowest values as a baseline, the most inexpensive extensive roofs are in Asia while the most expensive ones are in America, which shows a difference of more than four times. As an expected finding, unit construction costs of intensive roofs are at least two times higher than those of extensive roofs and similarly vary in a very large interval between \$165-540 for the American region and \$178-256 for the Asian region. Although the difference between the lowest and highest values in the same region or country is not very high, it can be more than three times, denoting a serious difference. However, the lowest values of American and Asian regions are very similar. Main factors affecting the unit construction cost can be listed as the quality of materials and the cost of labor. As a result, it seems impossible to standardize unit construction costs of green roofs in any region or country, and thus, it is a necessity for investors to assess current market prices of construction materials to be used and regional labor costs.

As can be seen in Tables 1 and 2, life cycle costing methods used in past studies are net present value (NPV), benefit-cost ratio (BCR), payback period (PBP), breakeven point (BEP), savings to investment ratio (SIR), adjusted internal rate of return (AIRR), and discounted payback period (DPBP). Among them, NPV is the most frequently used method. However, three methods (i.e., SIR, AIRR, and DPBP) were used in one research only. In conclusion, life cycle costing methods used in different regions of the world seem not to change.

In terms of lifespan of green roofs, there is no common attitude in past studies. This is also valid for comparisons between extensive and intensive roofs and between geographical regions. However, as lifespan was taken 40 years in most of these studies, it seems to be reasonable to accept the average lifespan of any kind of green roofs as 40-50 years which is equal to the lifespan of an ordinary reinforced concrete building [36].

Among all life cycle costing parameters, interest rate is likely the most uncertain input and its variation can lead to an overestimation or underestimation of the total cost [37]. Considering previous studies, it is evident that neither extensive and intensive roofs nor geographical regions have specific interest rates. These values change in a relatively small interval between 2-8\%. In fact, almost all of past researches were carried out in developed economies. Accordingly, this low and stagnant level of the presented interest rates may turn to high and unstable rates in undeveloped economies, indicating a warning signal for potential green roof investors while making their decisions on the roof type.

\subsection{Benefits of green roofs}

Benefits of green roofs may be divided into three main categories such as economic, environmental, and social, as given in Table 3. Economic benefits are energy saving, longer roof life, increased property value, and other cost savings. Environmental benefits include storm water management, improved air quality, mitigation of urban heat island effect, and increased biodiversity. Social benefits contain fire protection, green space, thermal insulation, noise insulation, and aesthetic view [30]. In fact, these three categories cannot be assessed individually because economic benefits may also provide environmental and/or social benefits and vice versa. For example, energy saving contributes to less energy production and thereby to reduction in greenhouse gas and $\mathrm{CO} 2$ emissions, leading to richer biodiversity and healthier living conditions. In other words, types of benefits should not be perceived as totally independent factors, but as integrated and engaged advantages. 
Table 3. Benefits of green roofs

\begin{tabular}{|c|c|c|c|c|c|c|c|c|c|c|c|c|c|c|c|}
\hline \multirow[b]{2}{*}{ Author(s) } & \multicolumn{6}{|c|}{ Economic Benefits } & \multicolumn{4}{|c|}{ Environmental Benefits } & \multicolumn{5}{|c|}{ Social Benefits } \\
\hline & 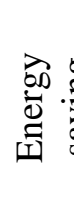 & $\begin{array}{l}4 \\
0 \\
0 \\
0 \\
0 \\
0 \\
0 \\
0 \\
0 \\
0\end{array}$ & & & 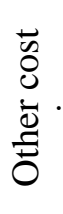 & 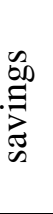 & 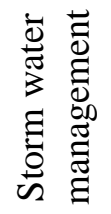 & 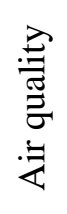 & 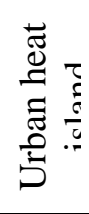 & 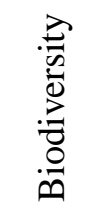 & 总 & 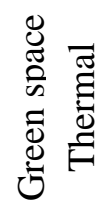 & 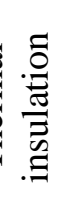 & 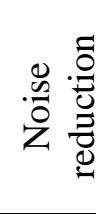 & 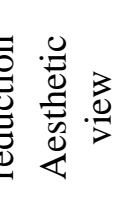 \\
\hline Porsche and Köhler [15] & & & $\mathrm{X}$ & & & $\mathrm{X}$ & & & & & & $\mathrm{X}$ & $X$ & & \\
\hline Wong et al. [31] & $\mathrm{X}$ & $X$ & & & & & & & & & & & & & \\
\hline Clark et al. [4] & $\mathrm{X}$ & & & & & $\mathrm{X}$ & $X$ & & & & & & & & \\
\hline Carter and Keeler [5] & $X$ & $\mathrm{X}$ & & & & $\mathrm{X}$ & $\mathrm{X}$ & $\mathrm{X}$ & & & $\mathrm{X}$ & & & & \\
\hline Blackhurst et al. [9] & $\mathrm{X}$ & & & & & $\mathrm{X}$ & & $X$ & & & $\mathrm{X}$ & & & & \\
\hline Niu et al. [18] & $X$ & & & & & $\mathrm{X}$ & $\mathrm{X}$ & & & & & & & & \\
\hline Lee et al. [29] & & & & & & $\mathrm{X}$ & & & & & & & & & \\
\hline Tsang and Jim [26] & $X$ & & & & & $\mathrm{X}$ & & & & & $X$ & & & & \\
\hline Wu and Smith [19] & $X$ & $X$ & & & & $\mathrm{X}$ & $X$ & & & & & & & & \\
\hline Bianchini and Hewage [20] & $\mathrm{X}$ & $X$ & $\mathrm{X}$ & $\mathrm{X}$ & & $\mathrm{X}$ & $X$ & $\mathrm{X}$ & $\mathrm{X}$ & & $\mathrm{X}$ & & & & $\mathrm{X}$ \\
\hline Claus and Rousseau [12] & $X$ & $X$ & $\mathrm{X}$ & $X$ & & $\mathrm{X}$ & $X$ & $\mathrm{X}$ & $\mathrm{X}$ & $\mathrm{X}$ & & & $x$ & $\mathrm{X}$ & $\mathrm{X}$ \\
\hline Liu and Hong [31] & $X$ & $X$ & & $\mathrm{X}$ & & & & & & & & & & & \\
\hline Angelakoglou et al. [25] & $X$ & & & & & & & & & & & & & & \\
\hline Chan and Chow [27] & $X$ & & & & & & & & & & & & & & \\
\hline Mullen et al. [21] & $X$ & & & & & $\mathrm{X}$ & $\mathrm{X}$ & & & & & & & & \\
\hline Joksimovic and Alam [23] & & & & & & $\mathrm{X}$ & & & & & & & & & \\
\hline Sproul et al. [22] & $X$ & $X$ & & & & $\mathrm{X}$ & $\mathrm{X}$ & $\mathrm{X}$ & & & & & & & \\
\hline Langston [34] & $X$ & $X$ & & & & $\mathrm{X}$ & $X$ & & & & $\mathrm{X}$ & $\mathrm{X}$ & $x$ & $X$ & $\mathrm{X}$ \\
\hline Liu et al. [33] & & & & & & $\mathrm{X}$ & $X$ & & & & & & & & \\
\hline Peng and Jim [28] & & & & & & & $X$ & $\mathrm{X}$ & & & & $\mathrm{X}$ & & & \\
\hline Shin and Kim [30] & $X$ & & & $\mathrm{X}$ & & $X$ & $\mathrm{X}$ & $\mathrm{X}$ & & & & & & & \\
\hline Zhang et al. [16] & $X$ & & & & & $\mathrm{X}$ & & & & & & & & & \\
\hline Chui et al. [17] & $X$ & & & & & $\mathrm{X}$ & & & & & & & & & $X$ \\
\hline
\end{tabular}

\subsubsection{Economic benefits}

A building's energy use for heating and cooling is an important component of its sustainable design [5]. Green roofs have potential to decrease the energy consumption of a building. Energy savings associated with the increased insulation depend on the size of a building, the climate zone, and the type of roof [12]. The amount of energy savings is expected to be between $40-110 \%$ in Hong Kong, compared to other roofs [27], 1.5\% in Belgium [12], and 3.3\% in the USA [5]. In this regard, electricity prices per kWh are $\$ 0.185$ in Hong Kong [27], $\$ 0.140$ in Belgium [12], and $\$ 0.069$ in the USA [19]. As a result, both saving amount and its monetary value seem not to change regionally. However, the monetary value is clearly prone to much higher values in many countries, presenting a larger room and motivation for such a saving.

Protection of green roof membranes through the reduction in surface temperature by multiple layers results in a two or three times longer roof life $[5,10,12,18,20,22,31,32,34]$. In this context, as the effect of sunlight on the roof life will show totally different characteristics from a region to another, it needs to be investigated by future studies.

Green roofs may contribute to increase the market value of properties via aesthetics. The increase rate varies between $2-5 \%$ [20] in property values and reaches up to $25 \%$ in hiring prices [15]. From the regional point of view, both land cost and property value will likely rise in highly urbanized regions subject to dense population and suffering from the lack of green areas.

Lastly, there are some policies applied by governments to encourage investors for the use of green roofs. In New York, one-time tax reduction of $\$ 48 / \mathrm{m} 2$ is allowed [20]. Similarly, the Flemish government in Belgium stimulates municipalities to grant subsidies of at least $\$ 36.16 / \mathrm{m} 2$ [12]. Hence, these kinds of direct cost savings seem to be a mission of regional administrations in increasing green areas. 


\subsubsection{Environmental benefits}

The most cited type of environmental benefits is storm water management. Green roofs reduce storm sewer pipe size, water utility fee [5], costs of upgrading storm water infrastructure [22], and storm water tax rate [12]. While storm water fees in some cities of Germany have been reduced for buildings with green roof, investors in Switzerland take 20\% of the cost of their investment back through storm water management [38]. In the USA, building owners could annually save between $\$ 0.08 / \mathrm{m} 2$ [4] and $\$ 0.38 / \mathrm{m} 2$ [20] by reducing storm water runoff amount. In South Korea, annual storm water runoff decreases 14.7-25.6\% [30]. All these findings reveal the significance of storm water management practices and policies that can be applied and adjusted according to regional precipitation amounts.

Green roofs are also expected to have positive effects on air quality improvement [4, 19]. The corresponding monetary value is calculated considering mitigation or prevention of air pollutants and thereby reduction of taxes and other legal payments. The monetary value of mitigation of NOX in the USA was calculated $\$ 1.07 / \mathrm{m} 2$ by Clark et al. [4] and Mullen et al. [21], $\$ 0.03 / \mathrm{m} 2$ by Bianchini and Hewage [20], and $\$ 0.011 / \mathrm{m} 2$ by Sproul et al. [22]. It is $\$ 0.43 / \mathrm{m} 2$ in Belgium [12] and $\$ 0.085 / \mathrm{m} 2$ in Hong Kong. In terms of SO2 and CO2, the monetary value of their prevention was taken $\$ 0.013 / \mathrm{m} 2$ and $5.7 \mathrm{~kg} / \mathrm{m} 2$, respectively. From a general perspective, the mitigation of all air pollutants will provide a $\$ 60$ benefit per year [19]. Since the amount of these polluting compounds can take totally different values in different regions and environmental policies (i.e., sanctions and incentives) can change with region, more regional researches seem to be necessary for a better life cycle analysis.

Urban heat island (UHI) increases energy consumption, concentration of harmful pollutants, emissions of $\mathrm{CO} 2$ to the atmosphere, and affects health conditions [39]. Green roofs reduce the UHI effect by providing a medium for evapotranspiration and altering the surface albedo [9]. However, some authors [5, 31, 32] define this benefit as speculative while others tend to include it in life cycle costing analysis $[9,12,20,22]$. In conclusion, as the amount of the UHI mitigation will vary between regions owing to their urbanization levels and climate conditions, green roof investments should be supported by governments given their environmental advantages regardless of financial revenues.

Biodiversity is described as the variety of living organisms, ecological complexes in which they occur, and ways in which they interact with each other and the physical environment [40]. There is no doubt that green roofs have potential to enhance biodiversity although this benefit is not represented in the life cycle costing analysis due to unavailability or unreliability of data $[12,20]$. In addition, it is very difficult to evaluate regional effects of the increased biodiversity. Consequently, similar to the UHI effect, the increased biodiversity could be used as a qualitative motivator.

\subsubsection{Social benefits}

Interestingly, these five benefits are also expected to provide indirect economic advantages to investors through the increased value and the marketable potential of property [15]. First, thermal and sound insulation potentials of green roofs may decrease or eliminate extra costs of insulation works in the construction phase and energy expenditures in the operating stage. On the one hand, it is difficult to calculate the thermal insulation effect because it depends on climate, the water content of layers, the water flow in the drainage layer, and the wind velocity [15]. On the other hand, the annual energy saving amount through the thermal insulation for extensive green roofs was calculated $57.6 \mathrm{kWh} / \mathrm{m} 2$ [28]. In terms of sound insulation, the annual monetary equivalent of this effect was accepted approximately $\$ 0.34 / \mathrm{m} 2$ [12]. Second, sedums in a roof are water retaining plants and might decrease the risk of fire. However, as this risk in one particular reinforced concrete building is extremely small, the fire protection feature of green roofs is neglected in life cycle costing analysis [12]. Third, the increased green recreation area especially by intensive roofs could improve the quality of life of residents [26]. It is a fact that green roofs do not provide positive social effects as much as parks do [20], but the reduction of stress and illnesses and an improved productivity [41]. Overall, regional differences seem to have a significant impact on all social benefits. Fire protection and thermal insulation is directly related with climate while green space, noise reduction, and aesthetic view is affected by the urbanization level. All of these arguments denote a regional aspect. As it seems difficult to obtain reliable input data, social benefits can constitute the qualitative aspect supporting the investment decision of potential building owners. 


\section{Conclusions}

As initial investment and maintenance costs of a green roof can be much higher than those of a conventional wooden or flat roof, many clients may be reluctant to invest in such a roof. This study is an attempt to reveal the findings of past researches about cost parameters and benefits of green roof investments in their life cycles. In doing this, an emphasis was naturally placed on the regional characteristic of such investments, which is a must to be taken into account in any life cycle costing analysis.

Generally speaking, there are three causes of the green roof choice of clients and they have financial drivers as an expected outcome. Looking at unit construction costs, they cannot be standardized and may have high variability. Therefore, current market prices of construction materials to be used and regional labor costs should be assessed in a detailed manner. Similarly, some economic factors (i.e., land cost, property value, and the effect of sunlight on the roof life) and all environmental benefits/policies (i.e., storm water management practices, the amount of the polluting compounds in the air and the related environmental regulations, the amount of the UHI mitigation, and the increased biodiversity) seem to be highly sensitive to regional characteristics and need for an in-depth investigation. This is also valid for all social benefits (i.e., fire protection, thermal insulation, green space, noise reduction, and aesthetic view). However, although these benefits can interestingly bring indirect financial gains via the increased value and the marketable potential of property, they can encourage the investment decision of potential clients qualitatively since it is difficult to compile reliable and concrete input data. On the contrary, life cycle costing methods do not change with region and NPV seems to be the most common approach in this regard. In this computation, the average lifespan of any kind of green roofs can be accepted 40-50 years. However, despite the fact that interest rates used up to date are low and stagnant, these rates may have a role to adversely affect the decision of potential green roof investors especially in undeveloped regions. Similarly, although energy saving amount and its monetary value do not have a regional effect, the monetary value may tend to rise in current global financial conditions and this may motivate potential customers more. In this context, governments may provide an additional motivation through tax reduction and/or subsidies to increase green areas.

Consequently, given the aforementioned results, it is seen that most of benefits and life cycle costing parameters are open to variation as the literature suggests and that life cycle costing evaluation of green roofs can be described case-sensitive. In other words, industrial professionals and potential green roof customers should consider parameters and benefits specific to that case and then calculate the economic viability of their particular investments. Keeping all these issues in mind, this study may enable industrial practitioners and potential clients to have a useful source of economic, environmental, and social information about green roofs and researchers to encourage for more region-specific studies.

\section{Acknowledgements}

The authors gratefully acknowledge financial supports provided by Committees on Research Grants of Bulent Ecevit University and Akdeniz University.

\section{References}

[1] O. Ortiz, F. Castells, and G. Sonnemann, "Sustainability in the construction industry: a review of recent developments based on LCA," Construction and Building Materials, vol. 23, pp. 28-39, 2009.

[2] L. Melchert, "The Dutch sustainable building policy: a model for developing countries?," Building and Environment, vol. 42, pp. 893-901, 2005.

[3] M. Zimmermann, H. J. Althaus, and A. Haas, "Benchmarks for sustainable construction: a contribution to develop a standard," Energy and Buildings, vol. 37, pp. 1147-1157, 2005.

[4] C. Clark, P. Adriaens, and F. B. Talbot, "Green roof valuation: a probabilistic economic analysis of environmental benefits," Environmental Science and Technology, vol. 42, pp. 2155-2161, 2008.

[5] T. Carter and A. Keeler, "Life-cycle cost-benefit analysis of extensive vegetated roof systems," Journal of Environmental Management, vol. 87, pp. 350-363, 2008.

[6] R. Kumar and S. C. Kausik, "Performance evaluation of green roof and shading for thermal protection of buildings," Building and Environment, vol. 40, pp. 1505-1511, 2005.

[7] T. L. Carter and L. Fowler, "Establishing green roof infrastructure through environmental policy instruments," Environmental Management, vol. 42, pp. 151-164, 2008.

[8] T. L. Carter and T. C. Rasmussen, "Hydrologic behaviour of vegetated roofs," Journal of the American Water Resources Association, vol. 42, pp. 1261-1274, 2007. 
[9] M. Blackhurst, C. Hendrickson, and H. S. Matthews, "Cost-effectiveness of green roofs," Journal of Architectural Engineering, vol. 16, pp. 136-143, 2010.

[10] S. W. Peck, C. Callaghan, M. E. Kuhn, and B. Grass, "Greenbacks from green roofs: forging a new industry in Canada," Peck \& Associates, Status Report prepared for Canada Mortgage and Housing Corporation, 1999.

[11] E. Oberndorfer, J. Lundholm, B. Bass, R. R. Coffman, H. Doshi, N. Dunnett, S. Gaffin, M. Köhler, K. K. Y. Liu, and B. Rowe, "Green roofs as urban ecosystems: ecological structures, functions, and services," BioScience, vol. 57, pp. 823-833, 2007.

[12] K. Claus and S. Rousseau, "Public versus private incentives to invest in green roofs: a cost benefit analysis for Flanders," Urban Forestry and Urban Greening, vol. 11, pp. 417-425, 2012.

[13] T. Hong, J. Kim, and C. Koo, "LCC and LCCO2 analysis of green roofs in elementary schools with energy saving measures," Energy and Buildings, vol. 45, pp. 229-239, 2012.

[14] W. Kloepffer, "Life cycle sustainability assessment of products," International Journal of Life Cycle Assessment, vol. 13, pp. 89-95, 2008.

[15] U. Porche and M. Köhler, "Life cycle costs of green roofs: a comparison of Germany, USA, and Brazil," in Proceedings of World Climate \& Energy Event, 2003, pp. 461-467.

[16] D. Zhang, R. M. Gersberg, W. J. Ng, and S. K. Tan, "Conventional and decentralized urban stormwater management: A comparison through case studies of Singapore and Berlin, Germany," Urban Water Journal, vol. 9006, pp. 1-12, 2015.

[17] T. F. M. Chui, X. Liu, and W. Zhan, "Assessing cost-effectiveness of specific LID practice designs in response to large storm events," Journal of Hydrology, vol. 533, pp. 353-364, 2016.

[18] H. Niu, C. Clark, J. Zhou, and P. Adriaens, "Scaling of economic benefits from green roof implementation in Washington, DC," Environmental Science and Technology, vol. 44, pp. 4302-4308, 2010.

[19] T. Wu and R. E. Smith, "Economic benefits for green roofs: a case study of the skaggs pharmacy building, university of Utah," International Journal of Design and Nature and Ecodynamics, vol. 6, pp. 122-138, 2011.

[20] F. Bianchini and K. Hewage, "Probabilistic social cost-benefit analysis for green roofs: a lifecycle approach," Building and Environment, vol. 58, pp. 152-162, 2012.

[21] D. Mullen, M. Lamsal, and G. Colson, "Green roof adoption in Atlanta, Georgia: the effects of building characteristics and subsidies on net private, public, and social benefits," Environmental Science and Technology, vol. 47, pp. 10824-10831, 2013.

[22] J. Sproul, M. P. Wan, B. H. Mandel, and A. H. Rosenfeld, "Economic comparison of white, green, and black flat roofs in the United States," Energy and Buildings, vol. 71, pp. 20-27, 2014.

[23] D. Joksimovic and Z. Alam, "Cost efficiency of Low Impact Development (LID) stormwater management practices," Procedia Engineering, vol .89, pp. 734-741, 2014.

[24] G. Peri, M. Traverso, M. Finkbeiner, and G. Rizzo, "The cost of green roofs disposal in a life cycle perspective: Covering the gap," Energy, vol. 48, pp. 406-414, 2012.

[25] K. Angelakoglou, M. Dimitriou, and G. Gaidajis, "Comparative evaluation of flat roof thermal systems in Greece," International Journal of Sustainable Building Technology and Urban Development, vol. 4, pp. 243-257, 2013.

[26] S. W. Tsang and C. Y. Jim, "Game-theory approach for resident coalitions to allocate green-roof benefits," Environment and Planning A, vol. 43, pp. 363-377, 2011.

[27] A. L. S. Chan and T. T. Chow, "Energy and economic performance of green roof system under future climatic conditions in Hong Kong," Energy and Buildings, vol. 64, pp. 182-198, 2013.

[28] L. L. H. Peng and C. Y. Jim, "Economic evaluation of green-roof environmental benefits in the context of climate change: The case of Hong Kong," Urban Forestry \& Urban Greening, vol. 14, pp. 554-561, 2015.

[29] K. Lee, H. Kim, G. Pak, S. Jang, L. Kim, C. Yoo, Z. Yun, and J. Yoon, "Cost-effectiveness analysis of stormwater best management practices (BMPs) in urban watersheds," Desalination and Water Treatment, vol. 19, pp. 92-96, 2010.

[30] E. Shin and H. Kim, "Analyzing green roof effects in an urban environment : a case of Bangbae-Dong, Seoul," Journal of Asian Architecture and Building Engineering, vol. May, pp. 315-322, 2015.

[31] L. P. Liu and G. X. Hong, "Popularizing path research on green roof project in China rural region: costeffectiveness assessment," in Proceedings of World Automation Congress (WAC), 2012. 
[32] N. H. Wong, S. F. Tay, R. Wong, C. L. Ong, and A. Sia, "Life cycle cost analysis of roof top gardens in Singapore," Building and Environment, vol. 38, pp. 499-509, 2003.

[33] Y. Liu, V. F. Bralts, and B. A. Engel, "Evaluating the effectiveness of management practices on hydrology and water quality at watershed scale with a rainfall-runoff model," Science of the Total Environment, vol. 511, pp. 298-308, 2015.

[34] C. Langston, "Green roof evaluation: a holistic "long life, loose fit, low energy" approach," Construction Economics and Building, vol. 15, pp. 76-94, 2015.

[35] L. Belussi and B. Barozzi, "Mitigation measures to contain the environmental impact of urban areas: a bibliographic review moving from the life cycle approach," Environmental Monitoring and Assessment, vol. 187, pp. 745-158, 2015.

[36] P. Ricci, F. De Luca, and G. M. Verderame, "6th April 2009 L'Aquila earthquake, Italy: reinforced concrete building performance," Bulletin of Earthquake Engineering, vol. 9, pp. 285-305, 2011.

[37] A. Ferreira and J. Santos, "Life-cycle cost analysis system for pavement management at project level: sensitivity analysis to the discount rate," Internal Journal of Pavement Engineering, vol. 14, pp. 655673, 2013.

[38] U. Berardi, A. GhaffarianHoseini, and A. GhaffarianHoseini, "State-of-the-art analysis of the environmental benefits of green roofs," Applied Energy, vol. 115, pp. 411-428, 2014.

[39] M. Santamouris and D. Kolokotsa, Urban Climate Mitigation Techniques, UK: Routledge, 2016.

[40] C. R. Groves, D. B. Jensen, L. L. Valutis, K. H. Redford, M. L. Shaffer, J. M. Scott, J. V. Baumgartner, J. V. Higgins, M. W. Beck, and M. G. Anderson, "Planning for biodiversity conservation: putting conservation science into practice," BioScience, 52, pp. 499-512, 2002.

[41] D. B. Rowe, "Green roofs as a means of pollution abatement," Environmental Pollution, vol. 159, pp. 2100-2110, 2011.

\section{BIBLIOGRAPHY OF AUTHORS}

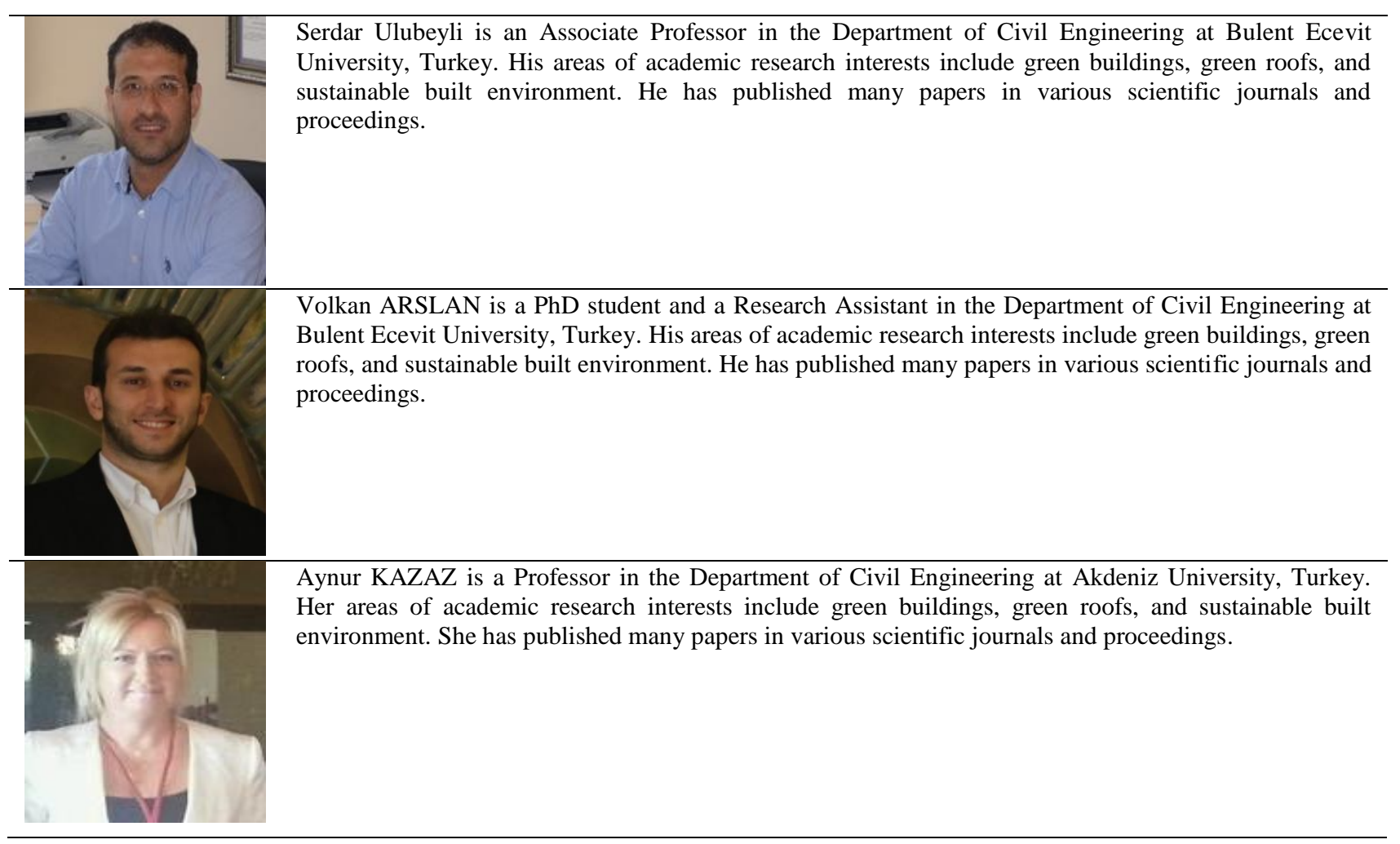

